\title{
PENGALAMAN KOMUNIKASI PASIEN PENDERITA GAGAL GINJAL KRONIK BERTAHAN HIDUP DENGAN HEMODIALISIS DAN CONTINOUS AMBULATORY PERITONEAL DIALYSIS (CAPD)
}

\author{
Faisal Reza $^{1}$, Eko Retno Wulandari ${ }^{2}$, Risa Nurisani ${ }^{3}$, Ika Merdekawati Kusmayadi ${ }^{4}$ \\ ${ }^{1}$ Universitas Informatika dan Bisnis Indonesia ${ }^{2,3,4}$ Universitas Padjadjaran \\ faisalreza@unibi.ac.id, eko@unpad.ac.id,risa@unpad.ac.id,i.m.kusmayadi@unpad.ac.id
}

\begin{abstract}
Abstrak
Penyakit gagal ginjal kronik di dunia saat ini mengalami peningkatan dan menjadi masalah kesehatan serius. Pengalaman pasien gagal ginjal kronik setelah menjalani terapi hemodialisis atau CAPD sangat bermanfaat bagi masyarakat. Tujuan penelitian ini yaitu untuk:(1) Mengetahui komunikasi dan pengalaman pasien gagal ginjal kronik setelah mereka divonis sebagai penderita gagal ginjal kronik.; (2) Mengetahui kondisi kesehatan pasien gagal ginjal kronik setelah mereka divonis sebagai penderita gagal ginjal kronik. Metode penelitian dengan menggunakan penelitian kaulitatif pendekatan fenomenologi. Berdasarkan penelitian diperoleh bahwa pengalaman pasien gagal ginjal kronik antara lain terapi rutin yang harus dilakukan adalah hemodialisis atau CAPD, aktivitas sehari-hari yang bisa dilakukan terbatas, pola makan dibatasi, pengaruh penyakit pada profesi pekerjaan menghambat, keterbukaan penyakit pada lingkungan sekitar tertutup. Sedangkan kondisi kesehatan pasien gagal ginjal kronik mengalami penurunan yang drastis dibandingkan dengan ketika masih sehat. Pasien gagal ginjal kronik dengan terapi $C A P D$ memiliki kondisi kesehatan yang lebih baik jika dibandingkan dengan pasien terapi hemodialisis.
\end{abstract}

Kata kunci: pasien gagal ginjal kronik, pengalaman komunikasi, kondisi kesehatan, Hemodialisis, $C A P D$

\begin{abstract}
Chronic kidney failure in the world is currently increasing and become a serious health problem. The experience of patients with chronic kidney failure after undergoing hemodialysis or CAPD therapy is very beneficial for the community. The purpose of this study is to explore: (1) the communication and experience of patients with chronic kidney failure after they were convicted as patients with chronic kidney failure; (2) the health condition of patients with chronic kidney failure after they were convicted as sufferers of chronic kidney failure. The research method uses phenomenology approach. Based on the research obtained, the experience of patients with chronic kidney failure, including routine therapy that must be done is hemodialysis or CAPD, limited daily activities, limited dietary patterns, the influence of disease on the occupational profession inhibits, openness of the disease in a closed environment. While the health condition of patients with chronic kidney failure has decreased dramatically compared to when they were still healthy. Patients with chronic kidney failure with CAPD therapy have better health conditions compared to patients with hemodialysis therapy.
\end{abstract}

Keywords: chronic kidney failure patients, communication experience, health conditions, hemodialysis, CAPD 


\section{PENDAHULUAN}

Penyakit gagal ginjal kronik di dunia saat ini mengalami peningkatan dan menjadi masalah kesehatan serius, hasil penelitian Global Burden of Disease tahun 2010, Penyakit Ginjal Kronis merupakan penyebab kematian peringkat ke 27 di dunia tahun 1990 dan meningkat menjadi urutan ke 18 pada tahun 2010. Lebih dari 2 juta penduduk di dunia mendapatkan perawatan dengan dialisis atau transplantasi ginjal dan hanya sekitar $10 \%$ yang benar-benar mengalami perawatan tersebut. Sepuluh persen penduduk di dunia mengalami Penyakit ginjal kronik dan jutaan meninggal setiap tahun karena tidak mempunyai akses untuk pengobatan. (Moeloek, 2018)

Ginjal mempunyai ukuran sebesar kepalan tangan merupakan organ tubuh yang terletak pada bagian belakang pinggang. Ginjal mempunyai peranan yang sangat penting dalam tubuh. Ginjal berfungsi menyaring kotoran, mengontrol jumlah air dalam tubuh, mengatur kadar garam dan mineral, dan mengatur tekanan darah. Kita mengeluarkan racun dan cairan berbahaya melalui keringat dan urin, saat gangguan kesehatan ginjal muncul kadar racun dan cairan dalam tubuh akan mengumpul dan tidak dapat dikeluarkan sendiri. Ginjal adalah organ tubuh yang ketika rusak tidak akan bisa diperbaiki lagi. Pasien gagal ginjal harus melakukan terapi pengobatan untuk meningkatkan kualitas hidup dan mempertahankan hidup.

Gangguan kesehatan ginjal terjadi ketika zat sisa metabolisme yang tidak berguna tidak bisa dikeluarkan dalam tubuh. Gangguan kesehatan ginjal biasanya ditandai dengan berkurangnya nafsu makan, perasaan tidak sehat, sesak napas, lemas, muntah, dan bengkak di pergelangan kaki. Gangguan ginjal yang tidak cepat ditangani mengakibatkan organ vital lain dalam tubun mengalami gangguan sehingga beresiko fatal menimbulkan kematian.

Gagal ginjal adalah penyakit ginjal kronis atau Chronic Kidney Disease (CKD). Ginjal yang sehat dapat membersihkan kotoran dari darah dan membuangnya cairan ekstra dari tubuh. Tetapi ketika ginjal tidak berfungsi dengan baik, limbah dan cairan ekstra dapat menumpuk dalam darah dan membuat pasien sakit. Peritoneal dialysis (PD) adalah pengobatan untuk orang yang mengalami gagal ginjal. (National Kidney Foundation, 2006) Penyakit gagal ginjal kronik harus menggunakan terapi pengganti ginjal yang menjadi satu-satunya pilihan untuk mempertahankan fungsi tubuh, terapi pengganti ginjal yang biasa dilakukan dapat berupa transplantasi ginjal, hemodialisis, dan dengan Continous Ambulatory Peritoneal Dialysis $(C A P D)$. (Smeltzer, Bare, Hinkle \& Cheever, 2008)

Hemodialis pada beberapa kasus biasanya penderita ginjal akut bisa dihentikan saat ginjal sembuh dan berfungsi baik seperti seharusnya. Namun pasien gagal ginjal kronis untuk mempertahankan hidupnya harus rutin menjalani terapi pengobatan dengan hemodialisis/ cuci darah dan tranplantasi ginjal/ cangkok ginjal, dengan penemuan teknologi di bidang kesehatan pasien penderita gagal ginjal kronik dengan Continous Ambulatory Peritoneal Dialysis (CAPD).

Hemodialisis (HD) merupakan tindakan untuk menggantikan fungsi ginjal dilakukan secara rutin. Hemodialisa adalah salah satu terapi pengganti ginjal yang menggunakan alat khusus dengan tujuan untuk mengeluarkan toksin uremik dan mengatur cairan, elektrolit tubuh. (RS Universitas Sumatera Utara, n.d.) Hemodialisis dilakukan untuk mengeluarkan sisa-sisa metabolisme atau racun tertentu dari peredaran darah manusia, seperti kelebihan ureum, kreatinin, asam urat, dan zat-zat lain melalui membran semipermeabel. Pasien PGK menjalani proses hemodialisis sebanyak dua sampai tiga kali seminggu, dimana setiap kali hemodialis rata-rata memerlukan waktu antara empat sampai lima jam. Rahman,et.al. dalam (Hasneli, 2017)

Transplantasi ginjal adalah tindakan cangkok ginjal dimana pasien digantikan dengan ginjal yang baru dan cocok dari pendonor ginjal. Transplantasi ginjal merupakan pengobatan terbaik bagi penderita gagal ginjal kronis, pasien dapat sembuh dan organ ginjal berfungsi kembali normal, tetapi tindakan pengobatan ini membtuhkan waktu yang cukup 
lama karena tidak mudah menemukan donor ginjal dan ginjal yang cocok bagi pasien. Sedangkan Continous Ambulatory Peritoneal Dialysis (CAPD) adalah alternatif pengobatan gagal ginjal kronis hampir sama dengan hemodialisis yaitu proses dialisis membuang cairan sisa metabolisme tubuh di dalam rongga perut yang bekerja sebagai penampung cairan dialysis, dan peritoeum sebagai membran semi permeable yang berfungsi sebagai tempat yang dilewati cairan tubuh yang berlebihan dan salut yang berisi racun yang akan dibuang.

Pasien penderita gagal ginjal kronis mengalami gangguan kesehatan yang komplek, pasien gagal ginjal juga rawan mempunyai penyakit komplikasi karena penyakitnya dengan banyaknya keluhan kesehatan, dan menurunnya aktivitas kegiatan sehari-hari yang bisa dilakukan. Pasien penderita gagal ginjal untuk mempertahankan hidupnya harus melakukan hemodialisis atau CAPD seumur hidup, butuh perjuangan dan semangat untuk tetap rutin melakukan terapi pengobatan ini. Dengan latar belakang tersebut peneliti tertarik untuk melakukan penelitian pada pasien penderita gagal ginjal kronik.

\section{Pertanyaan penelitian:}

Berdasarkan fokus penelitian yang telah diuraikan, maka pertanyaan penelitian dapat diidentifikasikan sebagai berikut (1) Bagaimana pengalaman pasien gagal ginjal kronik setelah mereka divonis sebagai penderita gagal ginjal kronik?; (2) Bagaimana kondisi kesehatan pasien gagal ginjal kronik?

\section{Tujuan Penelitian}

Adapun tujuan penelitian ini setelah apa yang telah dijelaskan dalam pertanyaan penelitian diatas yaitu untuk:(1) Mengetahui pengalaman pasien gagal ginjal kronik setelah mereka divonis sebagai penderita gagal ginjal kronik.; (2) Mengetahui kondisi kesehatan pasien gagal ginjal kronik setelah mereka divonis sebagai penderita gagal ginjal kronik.

\section{METODE PENELITIAN}

Metode penelitian dengan penelitian kualitatif menggunakan pendekatan fenomenologi. Pendekatan fenomenologi berupaya menjelaskan makna pengalaman hidup sejumlah orang tentang suatu konsep atau gejala termaksud pandangan hidup dari subjek sendiri. Pendekatan fenomenologi termasuk pada pendekatan subjektif atau interpretatif yang memandang manusia aktif. (Mulyana, 2008). Pendekatan fenomenologi menjadikan pengalaman hidup yang sesungguhnya sebagai data dasar dari realitas. Littejohn dalam (Mulyana, 2008).

Tradisi fenomenologi memfokuskan perhatiannya terhadap pengalaman sadar seorang individu, berpandangan bahwa manusia secara aktif menginterpretasikan pengalaman mereka, sehingga mereka dapat memahami lingkungannya melalui pengalaman personal dan langsung dengan lingkungan. Fenomenologi memberikan penekanan sangat kuat pada persepsi dan interpretasi dari pengalaman subjektif manusia, cerita atau pengalaman individu adalah lebih penting dan memiliki otoritas lebih besar. (Morissan, 2013)

Fenomenologi tidak beramsumsi bahwa peneliti mengetahui arti sesuatu bagi orangorang yang sedang diteliti oleh mereka. Inkuiri fenomenologi memulai dengan diam. Diam merupakan tindakan untuk menangkap pengertian sesuatu yang sedang diteliti, berusaha untuk masuk ke dalam dunia konseptual para subjek yang ditelitinya sedemikian rupa sehingga mereka mengerti apa dan bagaimana suatu peristiwa yang dikembangkan oleh mereka di sekitar peristiwa dalam kehidupan sehari-hari.(Moleong, 2000)

Wawancara langsung dilakukan kepada 3 orang informan dan 3 lainnya menggunakan chat Whatsapp. Wawancara dilakukan dengan informan secara langsung di tempat terapi hemodialisis di rumah sakit, di kantor dan dilakukan dengan Whatsapp untuk melengkapi hasil wawancara dan validasi data. Observasi dilakukan beberapa bulan, dengan melakukan pengamatan informan di tempat kerja.

\section{Informan}


Informan merupakan pasien gagal ginjal kronis merupakan pasien di beberapa rumah sakit antara lain RS AMC Cileunyi, dan RS khusus ginjal Ny. R.A.Habibie Bandung.

Tabel 1. Daftar Informan Pasien Penderita Gagal Ginjal Kronik

\begin{tabular}{|l|c|c|c|c|c|}
\hline No & $\begin{array}{c}\text { Nama } \\
\text { Informan }\end{array}$ & Umur & $\begin{array}{c}\text { Jenis } \\
\text { Kelamin }\end{array}$ & Pengobatan & Profesi \\
\hline 1 & NN & 49 th & Laki-laki & CAPD & Penjual Pulsa \\
\hline 2 & AG & 22 th & Laki-laki & CAPD & $\begin{array}{c}\text { Mahasiswa S1 tingkat } \\
\text { akhir }\end{array}$ \\
\hline 3 & AF & 38 th & Laki-laki & $\begin{array}{c}\text { Hemodialisis } \\
\text { 2x seminggu }\end{array}$ & PNS \\
\hline 4 & AP & 24 th & Perempuan & CAPD & Ibu Rumah Tangga \\
\hline 5 & OK & 40 th & Laki-laki & CAPD & Penjual Jus \\
\hline 6 & IK & 37 th & Laki-laki & $\begin{array}{c}\text { Hemodialisis } \\
\text { 2x seminggu }\end{array}$ & Mahasiswa S2 \\
\hline
\end{tabular}

Kriteria informan pada penelitian ini adalah pasien penderita gagal ginjal kronik, rutin menjalani terapi pengobatan hemodialisis minimal 2 kali seminggu atau menjalani terapi Continous Ambulatory Peritoneal Dialysis (CAPD).

Teknik pemeriksaan keabsahan data dilakukan dengan kriteria kredibilitas/ kepercayaan terdiri dari perpanjangan keikutsertaan, ketekunan pengamatan, triangulasi, pengecekan sejawat, kecukupan refrensial dan pengecekan anggota.(Moleong, 2012) Sedangkan teknik pemeriksaan keabsahan data dengan kriteria keteralihan, kebergantungan dan kepastian tidak dilakukan penulis karena keterbatasan waktu.

\section{HASIL DAN PEMBAHASAN}

Pasien gagal ginjal wajib melakukan terapi hemodialisis atau CAPD agar terhindar dari komplikasi beragam dan menghindari kematian. Dari wawancara diketahui bahwa rata-rata pasien gagal ginjal kronik dalam penelitian ini fungsi ginjalnya hilang sebanyak
$85-90 \%$, jadi hanya sekitar $10-15 \%$ yang berfungsi.

Pasien gagal ginjal kronik yang menggunakan terapi $C A P D$ sebelumnya juga menjalani terapi hemodialisis. Informasi tentang terapi $C A P D$ diperoleh dari mulut ke mulut sesama pasien gagal ginjal kronik yang telah sukses dan memiliki kualitas hidup yang lebih baik.

Informan bernama AG adalah adalah salah satu pasien dalam menggunakan terapi $C A P D$ dan sering diundang ke rumah sakitrumah sakit untuk berbagi pengalaman serta menjadi motivator bagi teman-temannya sesama pasien gagal ginjal kronik.

Informan dalam penelitian ini mempunyai profesi yang bermacam macam antara lain PNS, Ibu Rumah Tangga, mahasiswa, dan pedagang. Informan walaupun menderita gagal ginjal kronik masih melakukan aktivitas dalam pekerjaan dan profesinya.

Dibawah ini ditampilkan tabel pengalaman informan yang merupakan pasien gagal ginjal kronik: 
Tabel 3. Pengalaman Pasien Penderita Gagal Ginjal Kronik

\begin{tabular}{|c|c|c|}
\hline & \multicolumn{2}{|c|}{ Terapi Pengobatan } \\
\hline & Dengan Hemodialisis & Dengan $C A P D$ \\
\hline \multicolumn{3}{|l|}{ Pengalaman } \\
\hline $\begin{array}{l}\text { Kondisi } \\
\text { suasana hati } \\
\text { setelah divonis } \\
\text { gagal ginjal }\end{array}$ & \multicolumn{2}{|c|}{$\begin{array}{l}\text { - Putus asa, menderita, mengurung diri, } \\
\text { - Memerlukan waktu untuk bangkit, semangat dan menerima penyakit dengan } \\
\text { ikhlas } \\
\text { - Emosi mudah meledak-ledak, walaupun akhirnya menyadari dan meminta } \\
\text { maaf secara langsung atau hanya dalam hati }\end{array}$} \\
\hline $\begin{array}{l}\text { Terapi yang } \\
\text { harus } \\
\text { dilakukan }\end{array}$ & Cuci darah $2 x$ seminggu & $\begin{array}{l}\text { Melakukan pembersihan cairan dialisat } \\
\text { peritoneal extraneal } 4 \mathrm{x} \text { sehari per } 4 \text { jam }\end{array}$ \\
\hline Tempat Terapi & Rumah Sakit & $\begin{array}{l}\text { Bisa dilakukan di mana saja } \\
\text { Mempunyai ruang terapi sendiri, bersih, } \\
\text { ruang tanpa jendela, tidak ada angin yang } \\
\text { masuk }\end{array}$ \\
\hline $\begin{array}{l}\text { Aktivitas } \\
\text { sehari-hari }\end{array}$ & $\begin{array}{l}\text { - Mudah lelah ketika berjalan } \\
\text { - Mudah lelah ketika naik tangga } \\
\text { - Sering mengantuk } \\
\text { - Konsentrasi menurun }\end{array}$ & $\begin{array}{l}\text { - Lebih kuat berjalan, naik tangga } \\
\text { - Lebih kuat menajalani aktivitas sehari- } \\
\text { hari dibandingkan dg pasien terapi } \\
\text { hemodialisa } \\
\text { - Sering mengantuk } \\
\text { - Konsentrasi menurun }\end{array}$ \\
\hline Pola Makan & $\begin{array}{l}\text { Makanan dan minum dibatasi } \\
\text { (hampir semua buah dilarang, } \\
\text { minum diukur sesuai dengan } \\
\text { urin yang keluar, protein } \\
\text { dibatasi), jika melanggar/ } \\
\text { makan dan minum berlebih, } \\
\text { maka sesak napas) } \\
\text { - Bebas pantangan ketika } \\
\text { Hemodialisa (bebas makan dan } \\
\text { minum beberapa jam sebelum } \\
\text { dan ketika hemodialisa } \\
\text { berlangsung) }\end{array}$ & $\begin{array}{l}\text { - Lebih bebas makan dan minum } \\
\text { Asupan makanan yang masuk lebih } \\
\text { banyak dibandingkan dengan pasien } \\
\text { dengan terapi hemodialisis } \\
\text { - Menjaga pola makan dan porsi makan } \\
\text { - Memantang makanan yang membuat } \\
\text { pasien sesak napas/ memperparah } \\
\text { penyakitnya }\end{array}$ \\
\hline $\begin{array}{l}\text { Pengaruh } \\
\text { penyakit pada } \\
\text { profesi } \\
\text { pekerjaan }\end{array}$ & \multicolumn{2}{|c|}{$\begin{array}{l}\text { - Menghambat } \\
\text { - Banyak ijin/ tidak masuk kerja/ kuliah } \\
\text { - Kinerja menurun } \\
\text { - Motivasi berprestasi sedang dan ada yang menjawab rendah } \\
\text { - Keadaan sakit tidak diperlihatkan di depan teman kerja/ teman kuliah }\end{array}$} \\
\hline $\begin{array}{l}\text { Keterbukaan } \\
\text { penyakit } \\
\text { kepada } \\
\text { lingkungan } \\
\text { sekitar }\end{array}$ & \multicolumn{2}{|c|}{$\begin{array}{l}\text { Tertutup } \\
\text { Berusaha untuk menyembunyikan penyakitnya } \\
\text { Tidak ingin diketahui penyakitnya }\end{array}$} \\
\hline
\end{tabular}


Dalam Tabel 3. dijelaskan pengalaman pasien penderita gagal ginjal kronik antara lain: terapi yang dilakukan, aktivitas sehari-hari, pola makan, pengaruh penyakit pada profesi pekerjaan, keterbukaan penyakit dan kondisi suasana hati setelah divonis gagal ginjal kronik.

Dibawah ini ditampilkan tabel kondisi kesehatan informan setelah divonis gagal ginjal kronik:

Tabel 3. Kondisi Kesehatan Pasien Penderita Gagal Ginjal Kronik

\begin{tabular}{|c|c|c|}
\hline & \multicolumn{2}{|c|}{ Terapi Pengobatan } \\
\hline & Dengan Hemodialisis & Dengan $C A P D$ \\
\hline $\begin{array}{l}\text { Kondisi } \\
\text { Kesehatan }\end{array}$ & $\begin{array}{l}\text { - Mudah lelah, mengantuk,sesak napas } \\
\text { - Tekanan darah cenderung tinggi } \\
\text { - Hb turun ( sekitar 6-8 g/dL, normalnya } \\
\text { untuk laki-laki 14-18, perempuan 12- } \\
\text { 16) } \\
\text { - Sering tranfusi darah } \\
\text { Akibatnya kulit menghitam dan wajah } \\
\text { pucat } \\
\text { - Kelebihan cairan tubuh yang tidak bisa } \\
\text { dikeluarkan } \\
\text { Sehingga badan, kaki, tangan bengkak } \\
\text { - Lemas, sesak napas, gatal-gatal seluruh } \\
\text { tubuh, sulit tidur (gangguan tidur di } \\
\text { malam hari, sehingga siang hari } \\
\text { mengantuk) } \\
\text { - Setelah terapi hemodialisa merasakan } \\
\text { lemas sampai keesokan harinya, pasien } \\
\text { banyak tidur tidak bisa beraktivitas }\end{array}$ & $\begin{array}{l}\text { - Mudah lelah, kadang sesak } \\
\text { napas } \\
\text { - Tekanan darah tinggi } \\
\text { - Hb stabil } \\
\text { - Kondisi kesehatan lebih baik } \\
\text { daripada pasien yang } \\
\text { melakukan hemodialisa } \\
\text { - Tidur lebih berkualitas (lebih } \\
\text { nyenyak) }\end{array}$ \\
\hline $\begin{array}{l}\text { Pengecekan } \\
\text { kesehatan }\end{array}$ & $\begin{array}{r}\text { Rutin tiap bulan ke dokt } \\
\text { Cek laboratorium, minum obat tiga } \\
\text { Minum obat sesuai }\end{array}$ & $\begin{array}{l}\text { penyakit dalam } \\
\text { i sehari sesuai resep dokter } \\
\text { ep dokter }\end{array}$ \\
\hline
\end{tabular}

Informan ketika mengetahui divonis gagal ginjal merasa putus asa, semangat hidup meningkat ketika bertemu dengan sesama penderita pasien gagal ginjal kronik, mereka merasa tidak sendirian.

Kondisi suasana hati yang dialami informan setelah divonis gagal ginjal kadang sedih tidak bisa aktivitas seperti ketika sehat tapi tidak mereka ungkapkan kepada lingkungan sekitar. Awal ketika mengetahui divonis gagal ginjal kronik mereka mengurung diri, memerlukan waktu beberapa bulan untuk bangkit, semangat dan menerima penyakit dengan ikhlas. Emosi sering kali meledak-ledak, mudah marah, walaupun akhirnya menyadari dan meminta maaf kepada anggota keluarga secara langsung atau hanya dalam hati. Kadangkala muncul perasaan putus asa.
Semua informan dengan terapi hemodialisis melakukan cuci darah dua kali per minggu di rumah sakit, sedangkan pasien dengan terapi CAPD melakukan pertukaran cairan dialisat bisa dilakukan dimana saja, asalkan tempat bersih, tidak perlu steril. Informan pada penelitian ini lebih melakukan terapi $C A P D$ di rumah. Terapi $C A P D$ tidak menggunakan mesin dan tidak ada tusukan jarum.

Informan mengungkapkan tiap bulan rutin melakukan pengecekan kesehatan ke dokter penyakit dalam, cek laboratorium dan minum obat sesuai resep dokter. Obat yang harus diminum setiap hari sekitar 6 tablet diminum tiga kali sehari. Selain obat ada cairan untuk melakukan dialisis sendiri di rumah. Terapi $C A P D$ memungkinkan informan untuk 
melakukan dialisis sendiri di rumah. Terapi $C A P D$ cuci darahnya bisa dilakukan di rumah, di ruang khusus yang bersih, tidak banyak angin yang masuk. Dilakukan setiap 4 jam, sehari 4 kali.

Dalam beraktivitas sehari-hari pasien gagal gonjal kronik mengalami hambatan antara lain mudah lelah, lemas, kurang bertenaga, sering kali mengantuk dan konsentrasi menurun. Informan $\mathrm{NN}, \mathrm{AG}, \mathrm{AP}$, dan $\mathrm{OK}$ menjelaskan bahwa dengan terapi CAPD kondisi fisik lebih kuat melakukan aktivitas sehari-hari, rasa lemas juga berkurang. Hal ini seperti pernyataan AG.

Terapi CAPD membuat hidup menjadi berwarna lagi, saya bisa beraktivitas lebih banyak dibandingkan ketika masih cuci darah (hemodialisis). Saya berusaha menjalani hidup seperti sebelum sakit, setelah terapi CAPD saya bisa ke hutan dan berkemah seperti ketika masih sehat, dulu ketika cuci darah badannya lemas dan tidak bertenaga, sulit tidur, bahkan ketika cuci darah berlangsung badan menggigil karena ada infeksi pada alat yang dipasang di leher. ${ }^{1}$

Informan AF mengungkapkan bahwa aktivitas berkurang menjadi $40-50 \%$.

Mbak...kalau diukur dengan sebelum dan sesudah gagal ginjal, aktivitas yang bisa dilakukan tinggal $50 \%$ lah. $^{2}$

Dalam melakukan aktivitas kegiatan sehari-hari penderita gagal ginjal kronik mengalami hambatan, terutama dengan terapi hemodialisis kegiatan yang bisa dilakukan terbatas jika dibandingkan ketika sehat, dan mudah lelah. Contohnya tidak kuat naik tangga, berjalan pelan, ketika menyetir tiba-tiba mengantuk sehingga seringkali berhenti di jalan untuk istirahat. Sedangkan pada pasien dengan terapi $C A P D$ merasakan tubuhnya lebih bugar

\footnotetext{
${ }^{1}$ Wawancara dengan AG pada tanggal 14 Desember 2018

${ }^{2}$ Wawancara dengan $\mathrm{N}$ pada tanggal 8 Desember 2018
}

dan lebih sehat, bisa lebih banyak melakukan aktivitas seperti sedia kala.

Informan mengalami kesulitan dalam menyelesaikan pekerjaan di kantor atau di tempat kuliah, informan merasa penyakitnya menghambat pekerjaannya, karena sering dihinggapi rasa kantuk dan sering lemas. Hal ini tidak diperlihatkan di depan teman kerja atau teman kuliah. Pekerjaan tidak dapat memenuhi target. Informan sering ijin dan tidak masuk kerja/ kuliah karena kondisi badan yang drop dan keharusan mereka menjalani hemodialisis. Motivasi berprestasi informan dalam lingkungan kerja atau kuliah sedang dan ada yang menjawab rendah, tidak seperti ketika mereka sehat.

Semua informan ketika mereka berada di lingkungan kerja dan di kampus, mereka sangat tertutup terhadap penyakitnya. Tidak semua orang di lingkungan mereka mengetahui penyakit yang mereka idap. Jikapun ada orang yang mengetahui penyakit yang mereka idap, itu karena faktor ketidaksengajaan. Salah satunya diungkapkan IK, mahasiswa S2 di Perguruan Tinggi Negeri. IK berkata:

Ketika ada acara seminar dalam rangka memenuhi salah satu tugas mata kuliah, saya tidak bisa menjadi pemakalah karena berbarengan dengan terapi hemodialisis, sehingga saya membuat surat yang ditandatangani dokter RS. Saat itulah teman-teman tau saya menderita gagal ginjal. ${ }^{3}$

Informan $\mathrm{NN}, \mathrm{AG}, \mathrm{AN}$ dan $\mathrm{OK}$ mengungkapkan bahwa pola makan informan berubah setelah divonis sebagai pasien gagal ginjal kronik. Pasien dengan terapi CAPD lebih mendapat asupan makanan dan gizi yang berimbang. Hal ini seperti pernyataan oleh AG

Sewaktu menjalani terapi cuci darah tidak bisa makan sebebas ketika setelah menjalani CAPD, asupan makanan dan minum lebih banyak dan bervariasi. Dulu pas masih cuci darah dilarang makan

\footnotetext{
${ }^{3}$ Wawancara dengan AF pada tanggal 17 Desember 2018
} 
buah-buahan, sekarang tiap hari bisa makan buah-buahan. ${ }^{4}$

Sedangkan pasien terapi hemodialisis makanan dan minuman yang masuk ke dalam tubuh sangat dibatasi. Pasien dengan terapi hemodialisis bebas makan ketika proses hemodialisis berlangsung. Mereka makan dengan bebas dan melanggar pantangan sehingga mereka mengalami kadar ureum dan kreatinin yang tinggi serta kelebihan cairan yang tidak bisa dikeluarkan oleh tubuh. Salah satunya diungkapkan NN kepada penulis sewaktu hemodialisis berlangsung.

Kalau pas cuci darah gini, bebas makannya. Makanan yang tidak bisa dikonsumsi bisa dinikmati pas cuci darah berlangsung ${ }^{5}$

Rasa lemas dan konsentrasi menurun yang dirasakan penderita gagal ginjal kronik juga disebabkan oleh asupan gizi yang masuk ke tubuh terbatas. Tidak seperti orang sehat, penderita gagal ginjal kronik akan merasakan sesak napas jika berlebih makan (porsi makan masih normal untuk orang yang sehat). Asupan gizi yang berkurang ini menyebabkan pasien menderita mal nutrisi yaitu keadaan tubuh mengalami gangguan dalam pemenuhan zat gizi untuk pertumbuhan, perkembangan, dan aktivitas. Mal nutrisi sangat dirasakan oleh pasien gagal ginjal kronik dengan terapi hemodialisis (HD).

Dari wawancara diperoleh hasil bahwa kondisi fisik pasien gagal ginjal kronik dengan terapi hemodialisis (HD) makin hari semakin menurun. Setelah beberapa bulan terapi HD pasien merasakan lemas dan tidak bertenaga sampai keesokan harinya, sehingga pasien tidak bisa melakukan aktivitas sehari-hari. Keluhan yang sering dirasakan pasien dengan terapi HD adalah $\mathrm{Hb}$ turun sehingga sering tranfusi darah, kulit dan kuku menghitam, wajah pucat, lemas, sesak napas, gatal-gatal seluruh tubuh dan mengalami gangguan tidur.

\footnotetext{
${ }^{4}$ Wawancara dengan AG pada tanggal 17 Desember 2018

${ }^{5}$ Wawancara dengan AF pada tanggal 8 Desember 2018
}

\section{DISKUSI}

Pasien gagal ginjal kronik dengan terapi $C A P D$ memiliki kualitas hidup yang lebih baik dibandingkan dengan pasien gagal ginjal kronik dengan terapi hemodialisis. Keluhan pada pasien gagal ginjal kronik dengan terapi $C A P D$ berkurang,antara lain tidak mudah lelah, tidur lebih berkualitas, gatal-gatal berkurang, kaki tidak bengkak. Hal ini karena kadar ureum, kretanin, $\mathrm{Hb}$ pasien gagal ginjal kronik dengan terapi $C A P D$ lebih stabil dan cairan limbah hasil metabolisme tubuh dapat dikeluarkan lebih maksimal. Pasien gagal ginjal kronik dengan terapi $C A P D$ dapat mengkonsumsi makanan yang lebih bervariasi, dan minum lebih banyak, dengan pola makan yang diatur oleh masingmasing pasien berdasarkan keluhan yang dirasakan.

Yang perlu diwaspadai pada terapi $C A P D$ adalah kepatuhan terhadap standar $C A P D$, alat harus bersih sehingga tidak menimbulkan komplikasi infeksi merupakan penyakit atau luka yang berkembang selama perawatan dari penyakit atau gangguan fungsi tubuh yang sudah ada sebelumnya.(Indrastuti, 2010)

Penelitian ini juga bermanfaat bagi penderita gagal ginjal lainnya, bahwa tidak perlu takut untuk menjalani terapi hemodialis atau $C A P D$. Beberapa orang yang divonis gagal ginjal seringkali tidak mau melakukan terapi tersebut, padahal ketika dokter sudah menyarankan cuci darah pasien harus mentaati, karena jika pasien tidak mengikuti anjuran dokter, penyakitnya bertambah parah dan berujung pada kematian.

Karena keterbatasan waktu observasi dan wawancara, penelitian masih harus dilakukan dengan menambah jumlah informan dan untuk mengamati perilaku, kondisi kesehatan dan kualitas hidup pasien baik ketika di tempat kerja/ kampus dan di rumah.

Pasien gagal ginjal kronik dari tahun ke tahun meningkat sehingga diperlukan sosialisasi kepada masyarakat tentang pengobatan dan terapi yang dapat dilakukan oleh pasien gagal ginjal kronik untuk meningkatkan kualitas hidupnya. 


\section{KESIMPULAN}

Berdasarkan penelitian diperoleh bahwa pengalaman pasien gagal ginjal kronik antara lain terapi rutin yang harus dilakukan adalah hemodialisis atau $C A P D$, aktivitas sehari-hari yang bisa dilakukan terbatas, pola makan dibatasi, pengaruh penyakit pada profesi pekerjaan menghambat, keterbukaan penyakit pada lingkungan sekitar tertutup. Sedangkan kondisi kesehatan pasien gagal ginjal kronik mengalami penurunan yang drastis dibandingkan dengan ketika masih sehat. Pasien gagal ginjal kronik dengan terapi $C A P D$ memiliki kondisi kesehatan yang lebih baik jika dibandingkan dengan pasien terapi hemodialisis.

\section{REFERENSI}

Hasneli, Y. (2017). Hubungan Lama Menjalani Hemodialisis dengan Inter-Dialytic Weight Gain ( IDWG ) pada Pasien Hemodialisis Long-Term Relationship In Hemodialysis With Inter-Dialytic Weight Gain ( IDWG ) On Hemodialysis Patients. Jurnal Keperawatan Universitas Padjajaran, 5(3), 242-248. https://doi.org/10.24198/jkp.v5i3.646

Indrastuti, Y. (2010). Universitas Indonesia. Retrieved from http://lontar.ui.ac.id/file?file=digital/13726 5-T Yani Indrastuti.pdf

Moeloek, N. F. (2018). Disampaikan pada : Hari Ginjal Sedunia (World Kidney Day) 2018 dan Ulang Tahun PERSI Jakarta, 8. Retrieved from https://www.persi.or.id/images/2018/data/ materi_menkes.pdf

Moleong, L. (2000). Metodologi Penelitian Kualitatif. Bandung: Remaja Rosdakarya.

Moleong, L. (2012). Metodologi Penelitian Kualitatif Edisi Revisi. Bandung: Remaja Rosdakarya.

Morissan. (2013). Teori Komunikasi Individu
Hingga Massa. Jakarta: Prenamedia Group.

Mulyana, D. \& S. (2008). Metode Penelitian Komunikasi. Bandung: Rosda Karya.

National Kidney Foundation, I. (2006). Peritoneal Dialysis: What You Need to Know. Retrieved from https://www.kidney.org/sites/default/files/ docs/peritonealdialysis.pdf

RS Universitas Sumatera Utara. (n.d.). Hemodialisis. Retrieved from http://rumahsakit.usu.ac.id/index.php/id/dp t/haemodialysis

Smeltzer, S. C., Bare, B. G., Hinkle, J. L., \& Cheever, K. H. (2010). Brunner $\&$ Suddarth's textbook of medicalsurgical nursing(21 th edition ed.).Philadelphia: Lippincott Williams \&Wilkins. 